\title{
The intersection of basic research and conservation: a 30-year study of the Critically Endangered Schiedea adamantis (Caryophyllaceae) on Le'‘ahi (Diamond Head Crater), Hawai“i
}

\author{
Ann K. Sakai, Stephen G. Weller, Weigang Yang, Susan Ching Harbin \\ Talia Portner, Greg Mansker and Marie Bruegmann
}

\begin{abstract}
We report on how a long-term study of the reproductive biology of the Critically Endangered Schiedea adamantis (Caryophyllaceae), one of Hawai'i's rarest plant species, was leveraged for conservation purposes. Our major goals were to provide seeds with the greatest genetic variation possible for reintroduction and to ensure that both female and hermaphroditic plants of this wind-pollinated species were reintroduced in a manner that maximized both outcrossing and seed production. Schiedea adamantis was one of the first Hawaiian plant species listed under the Endangered Species Act (USA). The species has been studied intensively to test hypotheses addressing the evolution of breeding systems. Information on outcrossing levels and the extent of inbreeding depression was integrated into ongoing reintroduction efforts. Population size peaked in 1994, when 267 flowering individuals were found on Lē'ahi (Diamond Head Crater). By 2016 only 17 flowering individuals were present, with drought and invasive species being possible causes of this decline. Reintroduction attempts in 1998 using genetically diverse seeds were unsuccessful because of drought and a lack of sufficient supplemental irrigation. Additional reintroduction attempts in 2012 and 2014 were more successful because of increased supplemental irrigation. Plants used in reintroductions represent genotypes long since absent in the natural population, and may contain the genetic variability essential for evolutionary responses to climate change and the spread of invasive species. The destruction of many plants reintroduced in 2015 and 2016 by a fire in March 2016 highlights the need for additional restoration areas at Lē'ahi and elsewhere, and storage of seeds for future use.
\end{abstract}

\footnotetext{
Ann K. Sakai, Stephen G. Weller (Corresponding author) and Weigang Yang Department of Ecology and Evolutionary Biology, University of California, Irvine, CA 92697, USA. E-mail sgweller@uci.edu

Susan Ching Harbin and Talia Portner O'ahu Plant Extinction Prevention Program, Pearl City, Hawaii i, USA

Greg Mansker Division of Forestry and Wildlife, Honolulu, Hawai i i, USA

Marie Bruegmann United States Fish and Wildlife Service (retired), Dowagiac, Michigan, USA

Received 14 June 2016. Revision requested 5 August 2016.

Accepted 8 September 2016. First published online 20 February 2017.
}

Keywords Conservation, Diamond Head Crater, gynodioecy, Lè'ahi, reintroduction, reproductive systems, Schiedea adamantis, quantitative genetics

\section{Introduction}

$\mathrm{B}$ asic research questions on the evolution of reproductive 3 systems and the conservation of threatened species are often addressed independently by practitioners in these two areas. However, at a fundamental level both disciplines are united in the need to understand factors affecting population size and genetic variation. We report here a long-term study of the reproductive biology of one of Hawai'i's rarest plant species, and how the results were leveraged for conservation purposes. Our first major conservation goal for Schiedea adamantis St. John (Caryophyllaceae) was to provide seeds for conservation that represented the maximum level of genetic variation possible, using material collected prior to a severe decline in the size of the sole population of this species. An outplanting strategy was established to avoid inbreeding among closely related individuals. Our second major goal was to use our knowledge of the pollination and reproductive systems of $S$. adamantis to ensure that all plants used in restoration would have pollen sources close enough to ensure seed production.

Schiedea adamantis is among the rarest species of Schiedea, a lineage of 34 species descended from a common ancestor and endemic to the Hawaiian Islands (Wagner et al., 2005). The genus Schiedea, because of its diversity of breeding systems, has served as a model system for understanding the evolution of separate sexes (e.g. Weller et al., 1998; Sakai et al., 2006; Campbell et al., 2011). Schiedea adamantis has played a key role in testing hypotheses for the evolution of separate sexes because it is gynodioecious (female and hermaphroditic plants in a population), a breeding system intermediate between hermaphroditism and full dioecy (females and males in a population; Sakai et al., 1997). In gynodioecious species, females are necessarily outcrossed, whereas hermaphrodites may be outcrossing or potentially highly self-fertilizing. Information on reproductive systems is important for planning conservation efforts, to avoid the potential for deleterious effects caused by 
expression of inbreeding depression, and to ensure that pollination occurs in restored populations. Here we discuss the broader conservation impacts of a long-term study of the evolution of reproductive systems, and how features of the reproductive system, including the breeding system and pollination biology, may influence the outcome of restoration efforts. We focus on how a research programme can benefit conservation through cooperation between academic institutions and agencies charged with the protection of threatened species (conversely, basic research programmes may also benefit from conservation studies; e.g. Weisenberger et al., 2014; Weller et al., 2017). We report the population dynamics of $S$. adamantis over a 30-year period, and the results of reintroduction efforts using seeds produced from plants originally grown to study the reproductive system.

\section{Background on Schiedea adamantis}

Schiedea adamantis was discovered on Lē'ahi (Diamond Head Crater), Hawai i in 1955 and described in 1970 (St. John, 1970; Figs. 1 \& 2). It was one of the first Hawaiian plant species to be listed as endangered under the U.S. Endangered Species Act (Herbst, 1984), and also one of the first for which a recovery plan was prepared (U.S. Fish \& Wildlife Service, 1994; Fig. 1). Schiedea adamantis was categorized as Critically Endangered on the IUCN Red List in 2003 (Bruegmann \& Caraway, 2003). The sole remaining population occurs in a small area of lowland dry mixed community located on the rim of Léahi (two non-flowering plants discovered recently in the southern Ko'olau Mountains (T. Kroessig, pers. comm., September 2016) may represent $S$. adamantis), where other native species include Dodonaea viscosa (Sapindaceae), Eragrostis variabilis (Poaceae), Euphorbia celastroides (Euphorbiaceae) and Sida fallax (Malvaceae), and the most common introduced species is Leucaena leucocephala (Fabaceae; Plate 1). The area where S. adamantis occurs is striking for its high percentage $(18 \%)$ of bare rock, which may have reduced competition from other natives and especially from $L$. leucocephala. Although currently confined to Lē'ahi, S. adamantis apparently occurred more widely in south-east $\mathrm{O}^{\prime}$ ahu in the past; chloroplast genes from this species are found in Schiedea globosa from windward regions of south-east O'ahu (Willyard et al., 2011). Schiedea globosa, a widely collected and conspicuous coastal species (Wagner et al., 2005), has never been known to occur near Diamond Head Crater (Wagner et al., 2005), and therefore this gene exchange between species is more likely to be the result of more extensive occurrence of $S$. adamantis through south-eastern O'ahu in the past. The recent discovery of two plants in the southern Ko'olau Mountains that appear to be S. adamantis is also consistent with the more widespread past occurrence of the species in this region. The decline of S. adamantis and its eventual restriction or near restriction to Lē'ahi probably resulted from loss of suitable habitat, with increased development of south-east $\mathrm{O}^{\prime} \mathrm{ahu}$, and the effects of invasive species, as in the case of other species with extremely restricted ranges (e.g. Cogoni et al., 2013; Li et al., 2014).

Gynodioecious S. adamantis provided an excellent opportunity to understand the basis for the transition from hermaphroditism to dioecy in Schiedea, and how features of this reproductive system could influence conservation efforts. Studies of outcrossing and inbreeding depression in gynodioecious species have been especially important for testing models for the evolution of separate sexes (Charlesworth \& Charlesworth, 1978). These models suggest that when male sterility is controlled by nuclear genes, females may increase in frequency in largely hermaphroditic populations because females produce outcrossing offspring, whereas hermaphroditic individuals are more likely to selffertilize and produce offspring that suffer from the effects of inbreeding depression. Increased seed production of female plants relative to hermaphrodites may also favour females in populations. Using seeds collected from 53 field plants of S. adamantis in 1990, females had significantly higher levels of outcrossing than hermaphrodites (Sakai et al., 1997). Progeny that resulted from self-fertilization of hermaphrodites expressed strong inbreeding depression compared to progeny derived from outcrossing (Sakai et al., 1997), and females produced 2.3 times the number of seeds produced by hermaphrodites. Studies of $S$. adamantis provided a robust test for the Charlesworth \& Charlesworth (1978) model for the evolution of dioecy, and indicated that the joint occurrence of high levels of selfing and high expression of inbreeding depression, along with shifts in resource allocation patterns, would favour the evolution of dioecy through a gynodioecious pathway. These results also indicated clearly the importance of using genetically diverse individuals in conservation efforts, and maintaining opportunities for outcrossing in reintroductions. Failure to consider genetic variation during initial phases of reintroduction, which occurred for the Mauna Kea silversword Argyroxiphium sandwicense, can lead to population bottlenecks and substantial loss of genetic variability (Robichaux et al., 1997).

Prior to the dramatic decline in the $S$. adamantis population size in 1997, studies of allozyme markers indicated low genetic variability (a mean of 1.56 alleles per locus, $22.2 \%$ polymorphic loci, and an observed mean heterozygosity of 0.077; Weller et al., 1996) compared to other species of Schiedea with separate sexes and similar population size. Microsatellite markers demonstrated considerably higher genetic variability (relative to the allozyme study), with a mean of 3.67 alleles per locus, $83.3 \%$ polymorphic loci, and an observed mean heterozygosity of 0.291 (Culley et al., 2008). DNA for the microsatellite analysis was extracted from 49 individuals grown from seed also collected before 1997, when the population was still relatively large (Culley 


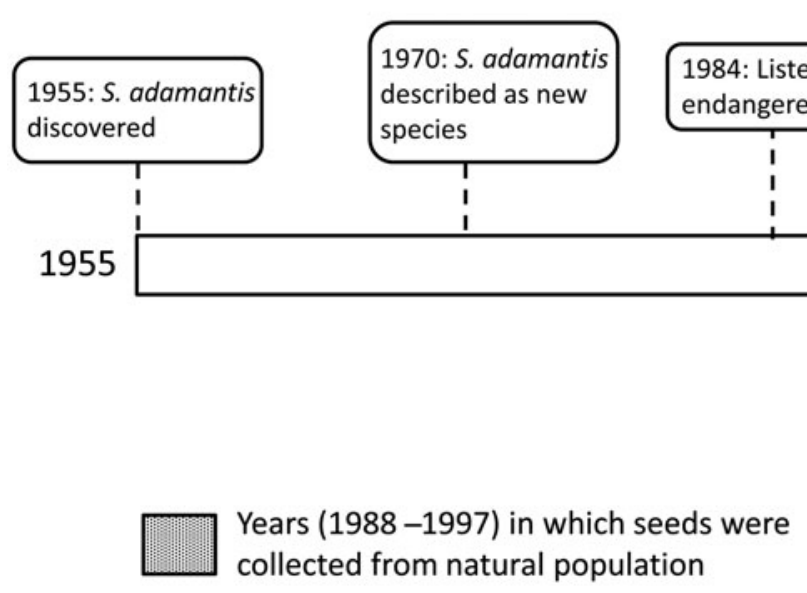

collected from natural population

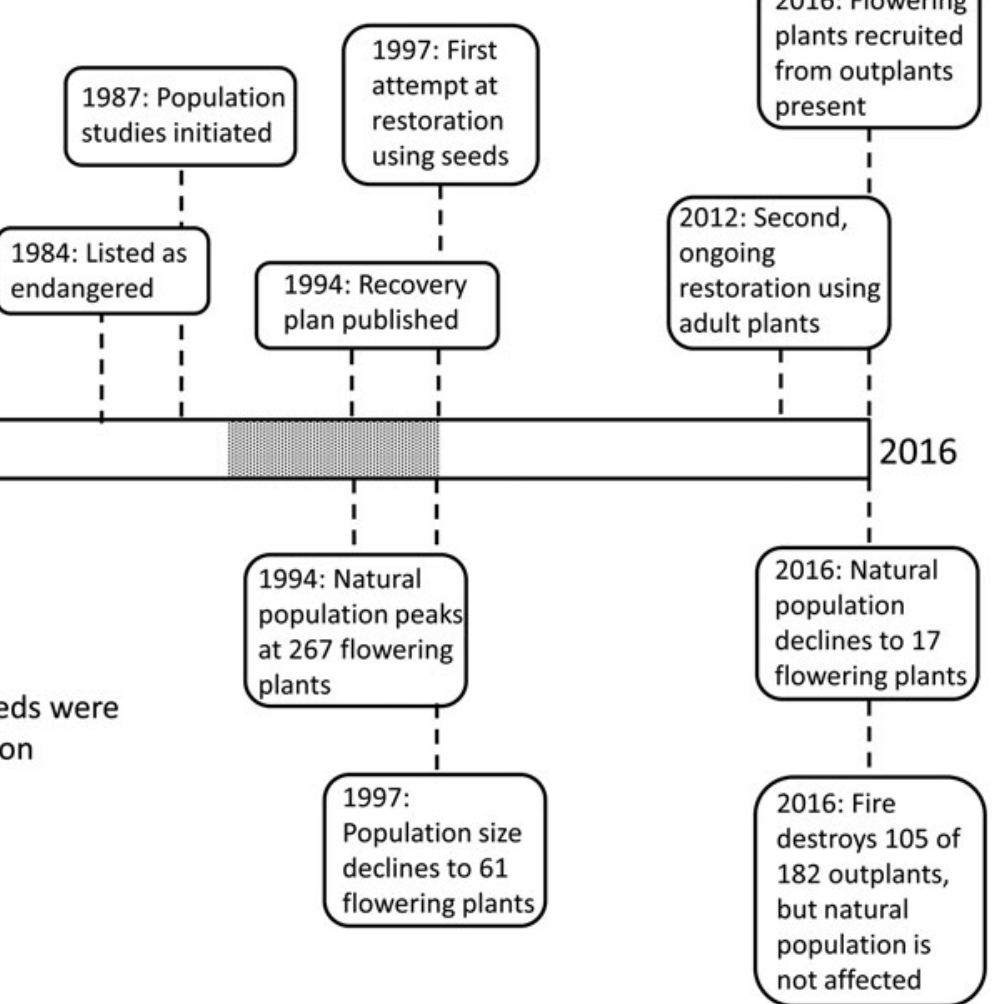

FIG. 1 Timeline for the history of Schiedea adamantis from the time of its discovery in 1955 to 2016 . Boxes above the line indicate events associated with human activities, including the species' discovery and description, and attempts to prevent its extinction, through seed banking and reintroduction. Boxes below the line indicate events in the natural population, including changes in population size and the occurrence of a fire in 2016.

et al., 2008). Despite the presumed decline in the range of $S$. adamantis from south-east $\mathrm{O}^{\prime}$ ahu to essentially a single population on Lé'ahi, genetic variability remained high in this population prior to the recent decline in population size. The high genetic variability in these plants suggested that seeds from plants collected before the population crash would be useful for reintroduction efforts.

\section{Variation in sex allocation in Schiedea adamantis}

The evolution of separate sexes requires not only natural selection for separate sexes (e.g. high levels of inbreeding depression combined with high levels of selfing favour selection for obligately outcrossing unisexual individuals) but also genetic variation in allocation of resources to respond to these selective pressures. We used S. salicaria ( $13 \%$ females), presumably at an early stage of gynodioecy, and S. adamantis (39\% females), presumably at a later stage of gynodioecy, to determine whether these gynodioecious species had the genetic variation (specifically, significant narrow-sense heritability) necessary to evolve greater differences in allocation to female biomass in females and male biomass in hermaphrodites, and potentially dioecy. Heritable variation for these traits indicated that $S$. adamantis would have the potential to respond to natural selection, both in traits related to reproductive allocation and in other traits associated with adaptation to potentially novel features of the habitats chosen for reintroduction. An important by-product of this study, unanticipated at the time of the original research, was the production of genetically diverse seeds representing a substantial number of genotypes from the natural population, which were eventually used for restoration.

We found strong heritable variation in sex allocation in both $S$. adamantis and closely related S. salicaria (Sakai et al., 2008, 2013; Campbell et al., 2011), and equally strong heritable variation in traits associated with wind pollination (Weller et al., 2006, 2007). These studies indicated that selection for increased allocation to male function in hermaphrodites and modification of floral and inflorescence traits associated with more effective wind pollination were promoting the evolution of dioecy for both species. From a conservation viewpoint, these studies indicated that even in this single remnant population of a Critically Endangered species, abundant quantitative genetic variation was present. High levels of quantitative genetic variation, combined 


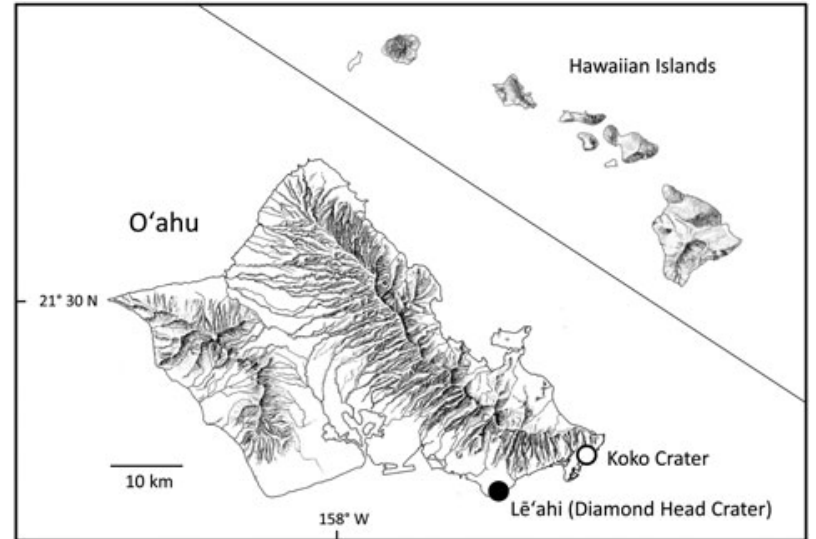

FIG. 2 The location of the natural population of S. adamantis on Lē'ahi, and plants growing at Koko Crater Botanical Garden, on the island of $\mathrm{O}^{\prime} \mathrm{ahu}$, Hawai' $\mathrm{i}$.

with high variation of genetic markers, suggested that reintroduction of a genetically diverse population of $S$. adamantis with the potential for further adaptation was feasible.

The quantitative genetic experiments required large numbers of unrelated paternal and maternal parents, albeit constrained by the time and space required for these crossing programmes. The parents of the $S$. adamantis plants used in a partial diallel crossing programme were derived from seeds collected in 1988, 1990, 1996 and 1997 from the natural population. These seeds were collected before the decline of the natural population, and progeny from the crosses had been maintained in the greenhouse. Without these individuals, reintroduction of a genetically diverse population would not have been possible. Because the quantitative genetic analysis of traits required that all families segregate both female and hermaphroditic offspring, all crosses in the programme were between females (genotype $h h$ ) and heterozygous hermaphrodites (genotype $H h$ ) that segregated both female and hermaphroditic offspring. Male sterility (expression of females) is controlled by a single nuclear gene in $S$. adamantis (Weller \& Sakai, 1991), and hermaphroditic plants may be homozygous dominant $(H H)$ or heterozygous $(H h)$. Because females were so common in the population, most hermaphrodites were heterozygotes and identified through earlier crosses. Thirty heterozygous hermaphrodites (genotype $H h$ ) from apparently unrelated maternal families (raised from seed collected in the field) were crossed as male parents to three unrelated females (genotype $h h$ ). Each of these females was also crossed to three hermaphrodites from different families. The crossing programme resulted in 90 full sibships, including 30 paternal half-sib families that were used to estimate narrow-sense heritability. The crossing programme maximized the genetic variation available in plants used for initial outcrossing studies, and provided the genetic material for reintroduction efforts.

\section{Field studies of the natural population}

Monitoring of the population size of flowering plants began in 1987, and detailed surveys continued until 1997, when two additional plants located $160 \mathrm{~m}$ west of the population were discovered. In all surveys extreme care was taken to avoid damaging plants in the natural population. After a hiatus, plants were surveyed again in December 2012, February 2014 and February 2016. The number of flowering plants declined from 267 in 1994 to 61 in 1997 , and only 17 by 2016 . The sex ratio reversed over this time period, from $39 \%$ females in 1994 to $59 \%$ females in 2016 (10 females and seven hermaphrodites). Currently, females may be pollen limited in the field, and inbreeding depression is likely among the progeny of these few remaining individuals.

In 1997 line transect surveys were used to characterize the vegetation at the natural population as well as at a nearby location intended for reintroduction. At the time of these surveys, native species dominated the natural population (61.6\% cover of native species; Table 1$)$. In the natural population, two native species had the greatest cover (E. variabilis, Poaceae, 34.1\% cover; Sida fallax, Malvaceae, 21.3\%), followed by three introduced species (Leucaena leucocephala, Fabaceae, 18.3\%; Reichardia tingitana, Asteraceae, 11.7\%; Bidens sp., Asteraceae, 6.72\%). Cover of living S. adamantis was $4.06 \%$ despite the large number of dead plants that provided the first evidence of the decline of this species. Cover of native vegetation at a second area on the rim of Lē'ahi designated for reintroduction was $40.4 \%$ (Table 1).

The goal of restoring $S$. adamantis was prompted by the rapid decline of the population, which began in 1997. Excess seeds from the partial diallel crossing programme were used in initial reintroduction efforts beginning in 1997, and were also stored ex situ at Lyon Arboretum (University of Hawai i i). Subsequent attempts to reintroduce $S$. adamantis depended on these seeds, and additional seeds using the same parental plants or their offspring that were maintained ex situ at the University of California, Irvine, and at Lyon Arboretum. A major goal of all reintroduction attempts for this species was to maximize genetic variation.

\section{Efforts to reintroduce S. adamantis in 1997-1998}

Reintroduction was attempted at two areas on the rim of Lè'ahi near the natural population, and three additional areas at more distant locations on the rim (Table 2). At one of the areas near the natural population much of the non-native vegetation was removed, although some L. leucocephala was left for erosion control (W. Garnett, pers. comm.). A steep cliff face behind the Kaimuki Fire Station (located c. $1 \mathrm{~km}$ north of the natural population) and two areas at the Koko Crater Botanical Garden 


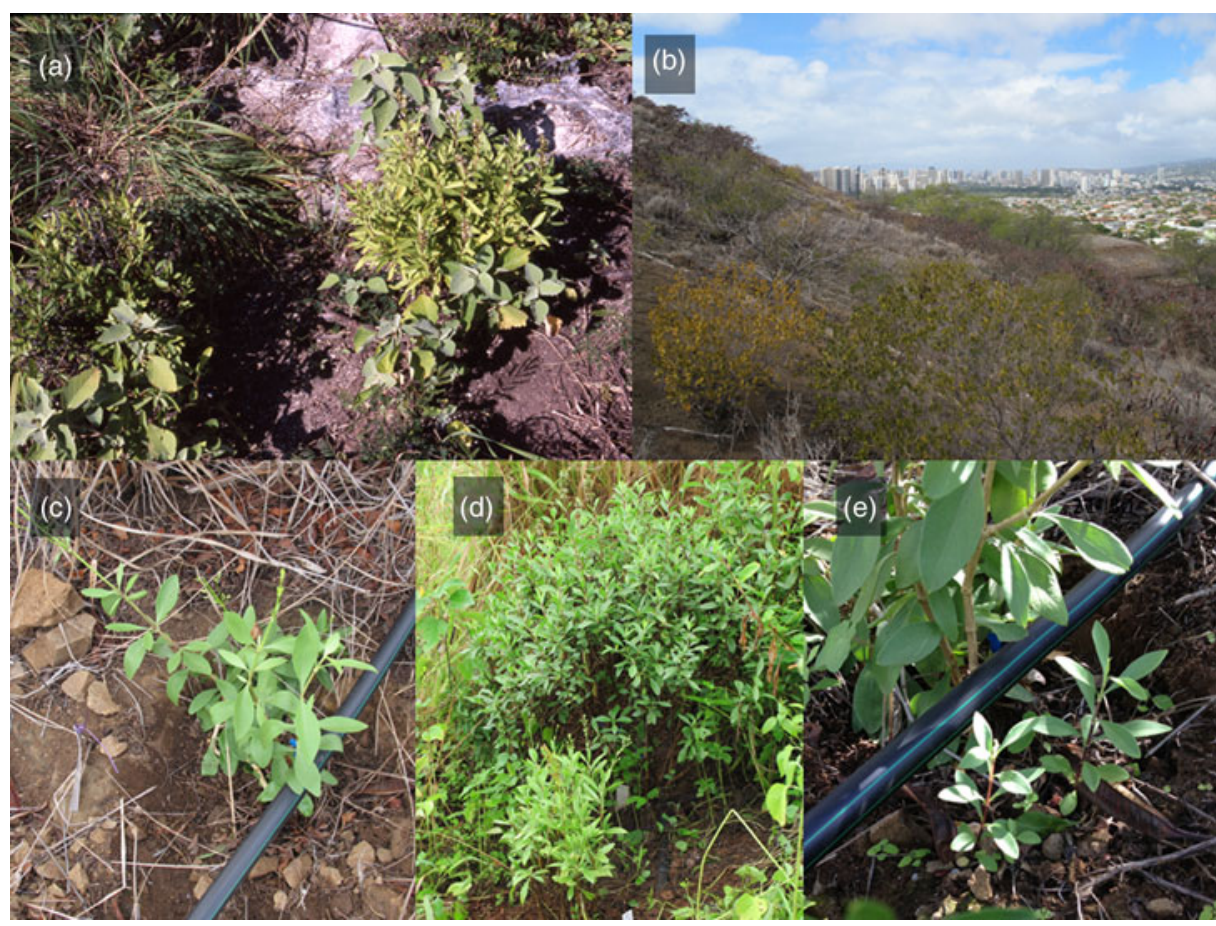

Plate 1 (a) A portion of the natural population of Schiedea adamantis on Lē'ahi, on the Hawaiian island of O'ahu (Fig. 2), in 1994, with two large individuals in the right and left centre; other native species visible include Sida fallax, Eragrostis variabilis and Euphorbia celastroides, and the introduced species Leucaena leucocephala is visible in the lower centre and right. (b) The site of the 2012 reintroduction of $S$. adamantis on Lē'ahi, with the Wai'anae Mountains visible in the distance. Shrubs with yellowing leaves in foreground are the indigenous Dodonaea viscosa. (c) A recently planted individual of $S$. adamantis adjacent to an irrigation line. (d) Two individuals of $S$. adamantis 1 year after they were outplanted on Lē'ahi. (e) An adult individual and two seedlings of S. adamantis c. 3 months after initiation of the 2012 reintroduction. Seeds were planted at the base of the adult plant, in an irrigated area.

(Fig. 2) were also chosen for additional outplanting of seeds. Approximately 100 seeds per cross were planted at each of the numerous planting sites within each restoration area and marked with a numbered aluminium tag in December 1997 at all sites, and again at each planting site in February and December 1998 at the cleared and uncleared reintroduction areas near the natural population on the rim of Lé'ahi. Crosses were allocated haphazardly at the planting sites, although an attempt was made to represent each cross as evenly as possible among the various planting sites. The rim areas close to the natural population on Lē'ahi and one of the Koko Crater areas were supplied with drip or microjet irrigation. Drip irrigation at Lē'ahi was supplied twice per week from December 1997, when the seeds were planted, until April 1998. Water was trucked to a portable tank located on the rim. At Koko Crater irrigation via the city water supply was carried out every other day for several months, and then as needed.

The 1997-1998 winter season was exceptionally dry as a result of an El Niño weather phenomenon. On Lē'ahi, supplemental watering at the rim areas was insufficient to stimulate germination, except for 21 seedlings that germinated in areas directly under emitters; no seeds germinated in areas without irrigation (Table 2). None of the 21 seedlings survived past the cotyledon stage. In subsequent years, which were also very dry, no seeds germinated on Lē'ahi from seeds planted in 1997 or in 1998. Because the level of germination was so low, the effects of matching the plant communities of the restoration areas and the natural population (Table 1), and the effect of removal of alien species could not be determined. At Koko Crater supplemental water at the irrigated area was sufficient to keep the seeds evenly moist, and germination was slightly $>10 \%$ at sites without mulch (at irrigated sites where mulch accumulated, germination was inhibited). Greenhouse test plantings of the same seed lots resulted in 48.8\% germination in December 1997. Two years later, in December 1999, plants in the irrigated, non-mulched area at Koko Crater were growing vigorously. Surviving plants had reached $0.5-0.75 \mathrm{~m}$ in height, many were in flower and a number of female plants had produced abundant capsules. By 2012 eight plants survived at Koko Crater from the 816 seedlings that germinated in 1997 (Table 2). A hybrid with wind-pollinated S. globosa had also appeared. Schiedea globosa is not cultivated at Koko Crater Botanical Garden; the most likely explanation for the hybrid plant is pollination of S. adamantis from plants of S. globosa growing naturally on the outer rim of Koko Crater. Occasional similar hybridization in the past, when the range of $S$. adamantis was greater, may explain the occurrence of some chloroplast DNA sequences of $S$. adamantis in some individuals of S. globosa. 
TABLE 1 Mean percentage cover of native and alien species (prior to partial removal of non-native species at the reintroduction area) at the location of naturally occurring Schiedea adamantis on Diamond Head Crater, O'ahu, Hawai'i (Fig. 2), based on four transect surveys, and at a reintroduction area c. $100 \mathrm{~m}$ east of the natural population (based on seven transects).

\begin{tabular}{|c|c|c|c|}
\hline \multirow[b]{2}{*}{ Species } & \multirow[b]{2}{*}{ Status } & \multicolumn{2}{|l|}{$\%$ cover $($ mean $\pm S D)$} \\
\hline & & Natural population & Reintroduction area \\
\hline Ageratum conyzoides $\mathrm{L}$. & Alien & & $3.21 \pm 2.74$ \\
\hline Antirrhinum orontium $\mathrm{L}$. & Alien & $3.84 \pm 2.65$ & $4.14 \pm 3.27$ \\
\hline Bidens pilosa $\mathrm{L}$. & Alien & $1.88 \pm 2.22$ & $5.39 \pm 2.87$ \\
\hline Bidens sp. & Alien & $6.72 \pm 8.01$ & \\
\hline Boerhavia sp. & & & $0.63 \pm 0.96$ \\
\hline Bothriochloa pertusa L. & Alien & $0.47 \pm 0.95$ & $0.63 \pm 0.96$ \\
\hline Cuscuta sandwichiana Choisy & Native & & $0.36 \pm 0.95$ \\
\hline Emilia fosbergii Nicolson & Alien & & $1.09 \pm 1.42$ \\
\hline Eragrostis variabilis (Gaud.) Steud. (living) & Native & $34.1 \pm 10.7$ & $24.0 \pm 18.8$ \\
\hline Eragrostis variabilis (Gaud.) Steud. (dead) & Native & $1.88 \pm 3.35$ & $2.02 \pm 2.48$ \\
\hline Euphorbia celastroides (Boiss.) Croizat \& Degener & Native & $0.563 \pm 0.53$ & $0.39 \pm 0.39$ \\
\hline Leucaena leucocephala (Lam.) de Wit (living) & Alien & $18.3 \pm 9.82$ & $44.8 \pm 12.9$ \\
\hline Leucaena leucocephala (Lam.) de Wit (dead) & Alien & & $1.25 \pm 2.07$ \\
\hline Lipochaeta lobata (Gaud.) DC & Native & & $0.63 \pm 1.40$ \\
\hline Panicum torridum Gaud. & Native & $1.25 \pm 2.50$ & $0.66 \pm 0.37$ \\
\hline Reichardia tingitana (L.) Roth. & Alien & $11.7 \pm 6.68$ & $7.94 \pm 7.24$ \\
\hline Schiedea adamantis St. John (living) & Native & $4.06 \pm 2.77$ & \\
\hline Schiedea adamantis St. John (dead) & Native & $0.47 \pm 9.38$ & \\
\hline Sida fallax Walp. & Native & $21.3 \pm 4.36$ & $14.3 \pm 5.34$ \\
\hline Stachys arvensis $\mathrm{L}$. & Alien & $0.063 \pm 0.13$ & $4.38 \pm 1.82$ \\
\hline Stapelia gigantea N.E. Brown & Alien & $2.72 \pm 2.72$ & $0.89 \pm 2.36$ \\
\hline Waltheria indica $\mathrm{L}$. & Native (?) & $0.63 \pm 1.25$ & \\
\hline Asteraceae 1 (unidentified) & Alien & & $0.089 \pm 0.24$ \\
\hline Asteraceae 2 (unidentified) & Alien & & $0.089 \pm 0.24$ \\
\hline Rock & & $18.0 \pm 3.13$ & $15.2 \pm 9.99$ \\
\hline Bare soil & & $2.19 \pm 2.58$ & \\
\hline Native cover (total) & & 61.8 & 40.4 \\
\hline
\end{tabular}

\section{Efforts to reintroduce S. adamantis in 2012 and subsequent years}

Continued decline of the natural population of S. adamantis and the failure of the 1997-1998 reintroduction efforts on Le' ahi indicated the need for additional attempts to reintroduce this species. Some seeds from the original partial diallel crosses remained in storage at Lyon Arboretum, and a number of the original plants used to produce these seeds remained in cultivation at the University of California, Irvine. Twenty-one female plants and 12 hermaphroditic plants grown from field-collected seeds, and 15 plants grown for the quantitative genetic study of resource allocation were used to produce seeds in 2011 for reintroduction purposes the following year. Each female was crossed to three unrelated hermaphrodites. Samples of seeds produced from these crosses were grown to flowering at the University of California, Irvine, to ensure that no contamination occurred before they were transferred to Lyon Arboretum for storage. The same crosses also remain in storage at the University of California, Irvine, under conditions similar to those at Lyon Arboretum $\left(-20^{\circ} \mathrm{C}\right.$, desiccated).
Repeated germination trials at the University of California, Irvine, indicate that the seeds retained there have high viability. These seeds have been used for current reintroduction efforts and thousands remain in storage for future conservation purposes. Seeds from 33 of the original quantitative genetics crosses stored since 1998 at the Lyon Arboretum were planted at the University of California, Irvine, in 2015 to test seed viability and to build reserves of genotypes no longer present in the natural population or among the plants at the university. Germination of these seeds averaged $53.7 \%$, indicating the feasibility of long-term storage of this species. Crosses among these plants were used to produce seeds for continued storage at Lyon Arboretum.

In the second phase of the effort to reintroduce $S$. adamantis, in 2012, the emphasis shifted to outplanting of individuals that were of flowering size, and the use of increased supplemental irrigation to improve the likelihood of establishment. Larger plants were used in this restoration effort because of the presumed greater likelihood of survival and the potential for rapid production of seeds; studies of other Critically Endangered species (e.g. Cogoni et al., 
TABLE 2 Planting area used for reintroduction of S. adamantis in 1997-1998, with the date of planting, the number of seeds planted at each site, the number of seedlings that had emerged by March 1998, and the number of seedlings 1 year after germination.

\begin{tabular}{|c|c|c|c|c|}
\hline Planting area & Date of planting & No. of seeds planted & $\begin{array}{l}\text { No. of emerged } \\
\text { seedlings, Mar. } 1998\end{array}$ & $\begin{array}{l}\text { No. of seedlings } 1 \\
\text { year after germination }\end{array}$ \\
\hline \multicolumn{5}{|l|}{ Lē'ahi } \\
\hline \multirow[t]{3}{*}{ Cleared reintroduction area (irrigated) } & 9 Dec. 1997 & 15,000 & 4 & 0 \\
\hline & 18-19 Feb. 1998 & 15,000 & 0 & 0 \\
\hline & 12 Dec. 1998 & 10,000 & 0 & 0 \\
\hline \multirow[t]{3}{*}{ Uncleared reintroduction area (irrigated) } & 11 Dec. 1997 & 5,500 & 12 & 0 \\
\hline & 18-19 Feb. 1998 & 5,500 & 0 & 0 \\
\hline & 12 Dec. 1998 & 10,000 & 0 & 0 \\
\hline Satellite A population (irrigated) & 11 Dec. 1997 & 5,000 & 5 & 0 \\
\hline Satellite B population & 11 Dec. 1997 & 3,100 & 0 & 0 \\
\hline Satellite $\mathrm{C}$ population & 11 Dec. 1997 & 1,800 & 0 & 0 \\
\hline Kaimuki Fire Station & 12 Dec. 1997 & 5,000 & Not surveyed & Not surveyed \\
\hline \multicolumn{5}{|l|}{ Koko Crater Botanical Garden } \\
\hline Rocky outcrop & 10 Dec. 1997 & 5,000 & 0 & 0 \\
\hline Irrigated area & 10 Dec. 1997 & 10,000 & 816 & 8 (in 2012) \\
\hline
\end{tabular}

2013) have also shown that larger plants are more likely to establish successfully. Plants of $S$. adamantis were grown at the Mokuleia Division of Forestry and Wildlife nursery from the seeds produced in 2011 and were planted in 2012 on the flank of Lē'ahi in an area with remnant native vegetation, including D. viscosa (Sapindaceae) and E. variabilis (Plate 1b). Outplants were also planted at Koko Crater Botanical Garden. All reintroduction efforts were carried out in partnership with the O'ahu Plant Extinction Prevention Program, the Division of Forestry and Wildlife, and Koko Crater Botanical Garden. In 2012 a total of 49 individuals of $S$. adamantis were planted along drip irrigation lines and supplied with a slow-release fertilizer (Plate 1c). Diverse microsites were chosen for outplanting, including areas of deeper vs shallow soils, and areas in full sun vs shade of $D$. viscosa. At the time of outplanting, continued drought had prevented germination of annual, mostly invasive species, and growth of native, mostly perennial species, including $D$. viscosa and the grass E. variabilis. At each irrigation site, seeds of $S$. adamantis from different crosses than those of the outplants were also planted in an effort to increase genetic variability of plants at each site, and to determine if establishment via seeds might be feasible at irrigated sites.

In an attempt to provide abundant sources of S. adamantis seeds that might establish naturally, additional plants grown from the same seeds used to produce the 2012 outplants were established in 10 irrigated 15 -gallon tubs in 2013 and 2014. The tubs were located in areas with thin soil cover and reduced numbers of alien plants. These rocky areas may be refugia for $S$. adamantis because of reduced competition from alien plants, and if the number of Schiedea seeds in these areas can be increased via greater propagule pressure, establishment of a viable population is more likely. To encourage recruitment from seed, irrigation was also provided downslope from these pots.

Plants transplanted directly into the substrate on Diamond Head Crater in 2012 were monitored for survival c. 1 year later, in early February 2014 (Plate 1d). Survival was highly variable, depending on the depth of soil and shading. Of the 49 outplants, $38(77.6 \%)$ survived (Table 3$)$. Survival appeared to be higher under the shade of $D$. viscosa $\left(\chi^{2}=6.35, \mathrm{df}=1\right.$, $\mathrm{P}=0.012)$. Of the survivors, half flowered, with a pronounced skew towards females ( $80 \%$ females, based on 19 flowering plants; Table 3). Flowering seemed to be unaffected by the presence of sparse or dense alien cover, or D. viscosa, although plants in areas of deeper soil with a thick cover of alien grasses seemed to be less vigorous than plants in areas of thinner soil with fewer alien species. Seedlings were present at only two of the 49 planting sites (Plate 1e), indicating that direct seeding of seeds produced in the greenhouse is not a feasible strategy for reintroduction of this species, even with supplemental irrigation. Outplanting near D. viscosa seemed to be beneficial in terms of survival after 1 year because of increased shade provided by this native shrub and/or the generally reduced cover of alien plants close to individuals of $D$. viscosa. Despite the higher survival, many of the S. adamantis plants near D. viscosa did not appear to be vigorous, perhaps because of increased competition from $D$. viscosa, which also appeared to benefit from irrigation. An additional 28 plants were transplanted in February 2014, and survival of these plants c. 6 months later was $93 \%$ (of the survivors, 12 female and 11 hermaphroditic plants flowered). These plants were located in areas of thin soil with reduced growth of alien plant species. Seven flowering plants recruited naturally from seeds produced by outplants were present by 2016 , indicating that the area chosen for reintroduction is suitable for regeneration of $S$. adamantis and possibly a sustainable population. In a study of Dianthus morisiana (Caryophyllaceae), Cogoni et al. (2013) also 
TABLE 3 Survival and flowering of outplants of S. adamantis (transplanted plants initially grown in a nursery) from December 2012. Outplants were placed in open areas or under the shade of Dodonaea viscosa. In addition to the outplants, c. 50 seeds were planted near each of the outplants.

\begin{tabular}{|c|c|c|c|c|c|c|}
\hline \multirow{2}{*}{$\begin{array}{l}\text { Survival c. } 13 \text { months } \\
\text { after outplanting }\end{array}$} & \multirow[b]{2}{*}{ No. of plants } & \multicolumn{3}{|c|}{ Reproductive type } & \multirow{2}{*}{$\begin{array}{l}\text { Seedlings present } \\
\text { near outplant }\end{array}$} & \multirow{2}{*}{$\begin{array}{l}\text { Shaded by } \\
\text { D. viscosa }\end{array}$} \\
\hline & & Female & Hermaphroditic & Vegetative & & \\
\hline$\overline{\text { Alive }}$ & 38 & 15 & 4 & 19 & 2 & 15 \\
\hline Dead & 11 & & & & 0 & 0 \\
\hline
\end{tabular}

regarded successful recruitment via seeds from outplants as an important measure of successful reintroduction.

Outplants in large tubs had high survival and flowered vigorously. Abundant recruitment from seeds dispersed from plants in these tubs occurred in several areas with rock outcroppings, indicating that seeds were produced in large numbers. Recruitment from plants in large tubs suggests that increased propagule pressure positively influences recruitment. Use of plants in tubs should be expanded to promote establishment of $S$. adamantis in areas of thin soil cover and rock outcroppings, where less competition from alien plants occurs. The ability of these and other reintroduced plants to produce seeds also suggests that wind speeds at the reintroduction area are sufficient to promote wind pollination of $S$. adamantis, a species with pronounced adaptations to this mode of pollination (Weller et al., 1998, 2007).

A second irrigated reintroduction area was subsequently established and an additional 60 plants of S. adamantis were planted on Lē'ahi in January 2015, and another 45 plants were added to this area in February 2016. All of the plants at the second reintroduction area were destroyed by a fire in March 2016. Fortunately, the natural population and the first reintroduction area were not affected.

\section{Recommendations for future efforts to reintroduce S. adamantis}

Based on the two attempts to reintroduce $S$. adamantis in 1997-1998 and 2012-2014, outplanting of mature individuals appears to be the approach most likely to lead to successful establishment. Use of supplemental irrigation appears to be essential. Precipitation at Lēahi has probably always been irregular, and levels of rainfall in any given year are unlikely to be adequate to promote establishment of recent outplants. The prospect of continued drying as a result of climate change further suggests that habitat modification through supplemental irrigation, at least until plants are established, is essential. Plants grown in irrigated tubs produced large numbers of seeds, and many of these germinated in rocky substrate where outplanting of mature plants would be difficult. With the presence of large numbers of invasive alien species, these rocky areas are likely to be the best current habitat for S. adamantis because of reduced competition from these alien plant species. If propagule pressure can be increased substantially in these areas, establishment of a viable population is more likely. Given our knowledge of the high levels of inbreeding depression in the population, genetic diversity of outplants should be maximized in all reintroduction efforts. For S. adamantis, genetic diversity can be maximized through the use of genetic combinations in ex situ collections representing all plants grown from field-collected seeds prior to the 1997 decline of the population (and from any new plants that are discovered). If the establishment of a new population is successful, the sex ratio of plants established on Lē'ahi is likely to approach a $1: 1$ ratio because all seeds were produced by crosses between females and hermaphrodites, which almost always yield equal numbers of the two sexes. An increase in the proportion of females relative to the number found in the natural population in 1994 is likely to select for increased allocation to male function in hermaphrodites and lead to selection for dioecy (Charlesworth \& Charlesworth, 1978) but this evolutionary transition was probably already in progress in the natural population before the extreme population bottleneck (Sakai et al., 1997).

In light of climate change and changing precipitation patterns, the natural population of $S$. adamantis may not persist. Location of additional areas for reintroduction of this species at higher elevations with greater precipitation may be helpful, although preliminary attempts to find suitable sites were not successful. At most potential areas with greater moisture, extensive site modification would be essential because of the high density of invasive alien species, and sustainable populations of $S$. adamantis that do not require regular maintenance would be difficult to establish. Further efforts should be made to find suitable areas for reintroduction, particularly in windward areas of southeastern $\mathrm{O}^{\prime}$ ahu with reduced cover of alien plant species (and where plants likely to be S. adamantis were recently discovered). Species with exceptionally limited distributions as a result of habitat loss present considerable challenges for restoration (e.g. Cogoni et al., 2013; Li et al., 2014); for S. adamantis, habitat management to reduce the impacts of invasive species may be essential at most potential restoration sites. At any area used for reintroduction, supplemental irrigation should be incorporated into planning. Ideally, 
protection from fire would also be possible. Additional outplantings, similar to those at Koko Crater, may be essential for providing backup of genetic resources used in current reintroductions, and for those seeds already stored at Lyon Arboretum. Seeds of $S$. adamantis remain viable for up to 17 years in storage, which provides additional options for finding successful combinations of outplanting techniques and restoration sites.

\section{Protecting the natural population}

Efforts to reintroduce S. adamantis have resulted in a population of 64 flowering-sized plants, compared to the 17 similarly sized plants in the natural population. Despite the apparent success in establishing plants, and the recruitment and flowering of offspring of these plants, to date most recruitment from seed has occurred in the natural population. The protection of this site, ideally with the enhancement of the number of the plants, is clearly crucial to the future of $S$. adamantis. Occasional supplemental irrigation during periods of prolonged drought may be essential for maintaining plants. A site near the rim of Diamond Head Crater with conditions similar to the natural population should be identified, provided with sufficient irrigation, and used for reintroduction, in addition to other sites on Lē'ahi. The destruction of recent outplants of $S$. adamantis by fire indicates the importance of these additional sites, and supports the statement in the recovery plan for S. adamantis (U.S. Fish \& Wildlife Service, 1994) that 'fire poses the greatest threat to quick and complete extinction of Schiedea adamantis.'

\section{Conclusion}

Basic research on the reproductive biology of Schiedea adamantis provided genetic material for restoration of this Critically Endangered species, and information useful for guiding the restoration effort. Seeds from crosses contained more genetic variation than is currently present in the remnant natural population, and may provide the genetic material essential for $S$. adamantis to evolve in response to climate change and to habitats altered by invasive species. Outplanting arrays with both female and hermaphroditic plants will promote outcrossed seed production of $S$. adamantis, and avoid the expression of strong inbreeding depression. Dense plantings of wind-pollinated S. adamantis will foster transfer of pollen from hermaphrodites to females, and prevent pollen limitation and low seed production. Thus through the intersection of basic research and conservation, genetic material and insights from basic research may improve the chances for successful conservation of this and other rare species.

\section{Acknowledgements}

We thank the U.S. Fish \& Wildlife Service (USFWS) for financial support, and the Division of Forestry and Wildlife (DOFAW) for continued support and for permission to work on this species (License No. P-2). We also thank USFWS for letters of transfer for seeds provided to Lyon Arboretum. Seeds used initially for reintroduction were produced in a quantitative genetic study supported by the National Science Foundation (DEB 9815878). Marion Chau and Tim Kroessig (Lyon Arboretum, University of Hawai $i$ ) stored and germinated seeds used in outplanting. Randy Kennedy and Bill Garnett (DOFAW) supported reintroduction efforts. Joshlyn Sands (Koko Crater Botanical Garden) supported efforts to maintain S. adamantis ex situ. Dave Lorence (National Tropical Botanical Garden) identified plants from the natural population site. The Federal Aviation Authority, Hawai'i National Guard, and Yara Lamadrid-Rose (Diamond Head State Park) provided access to field sites. Warren L. Wagner provided the maps modified for use in this publication.

\section{Author contributions}

AKS and SGW were responsible for the research on the reproductive system and pollination biology of S. adamantis, and the breeding programme used for the quantitative genetics experiments; they wrote the article with input from coauthors. WY carried out crossing programmes in the greenhouse that provided seeds used in outplanting and for storage at Lyon Arboretum. SCH was responsible for implementing recent restoration efforts on Lē'ahi, TP assisted in restoration efforts, and GM grew plants for use in outplanting, prepared restoration sites on Lé'ahi, and maintained plants at Koko Crater Botanical Garden. MB helped in outlining the nature of the conservation goals throughout the duration of this conservation effort, beginning in 1997, and facilitated access to the natural population.

\section{References}

Bruegmann, M.M. \& Caraway, V. (2003) Schiedea adamantis. The IUCN Red List of Threatened Species 2003: e.T44065A10854416. Http://doi.org/10.2305/IUCN.UK.2003.RLTS.T44065A10854416.en [accessed 30 November 2016].

Campbell, D.R., Weller, S.G., SAKai, A.K., Culley, T.M., Dang, P. N. \& Dunbar-Wallis, A.K. (2011) Genetic variation and covariation in floral allocation of two species of Schiedea with contrasting levels of sexual dimorphism. Evolution, 65, 757-770.

Charlesworth, B. \& Charlesworth, D. (1978) A model for the evolution of dioecy and gynodioecy. The American Naturalist, 112, 957-997.

Cogoni, D., Fenu, G., Concas, E. \& Bacchetta, G. (2013) The effectiveness of plant conservation measures: the Dianthus morisianus reintroduction. Oryx, 47, 203-206. 
Culley, T.M., Weller, S.G., SAKai, A.K. \& Putnam, K.A. (2008) Characterization of microsatellite loci in the Hawaiian endemic shrub Schiedea adamantis (Caryophyllaceae) and amplification in related species and genera. Molecular Ecology Resources, 8, 1081-1084.

Herbst, D.R. (1984) Endangered and threatened wildlife and plants; final rule to list Bidens cuneata and Schiedea adamantis as endangered species. Federal Register, 49, 6099-6101.

LI, B., ZHANG, Z. \& ZHANG, D. (2014) Conservation status of the unique population of Wenchengia alternifolia, an enigmatic plant endemic to Hainan Island, China. Oryx, 48, 354-357.

Robichaux, R.H., Friar, E.A. \& Mount, D.W. (1997) Molecular genetic consequences of a population bottleneck associated with reintroduction of the Mauna Kea silversword (Argyroxiphium sandwicense ssp. sandwicense [Asteraceae]). Conservation Biology, $11,1140-1146$.

Sakai, A.K., Weller, S.G., Campbell, D.R., Culley, T.M., Dunbar-Wallis, A.K. \& Andres, A.M. (2013) Measure for measure: comparing morphological and biomass traits for sex allocation in two gynodioecious species. American Journal of Botany, 100, 1071-1082.

Sakai, A.K., Weller, S.G., Chen, M.-L., Chou, S.-Y. \& Tasanont, C. (1997) Evolution of gynodioecy and maintenance of females: the role of inbreeding depression, outcrossing rates, and resource allocation in Schiedea adamantis (Caryophyllaceae). Evolution, 51, 724-736.

Sakai, A.K., Weller, S.G., Culley, T.M., Campbell, D.R., Dunbar-Wallis, A.K. \& Andres, A. (2008) Sexual dimorphism and the genetic potential for evolution of sex allocation in the gynodioecious plant, Schiedea salicaria. Journal of Evolutionary Biology, 21, 18-29.

Sakai, A.K., Weller, S.G., Wagner, W.L., Nepokroeff, M. \& Culley, T.M. (2006) Adaptive radiation and evolution of breeding systems in Schiedea (Caryophyllaceae), an endemic Hawaiian genus. Annals of the Missouri Botanical Garden, 93, 49-63.

ST. John, H. (1970) The "staminodia" of the genus Schiedea (Caryophyllaceae) and three new Hawaiian species. Hawaiian plant studies 32. Pacific Science, 24, 245-254.

U.S. Fish and Wildlife Service (1994) Recovery Plan for Schiedea adamantis. U.S. Fish and Wildlife Service, Portland, USA.

Wagner, W.L., Weller, S.G. \& SAKai, A.K. (2005) Monograph of Schiedea (Caryophyllaceae subfam. Alsinoideae). Systematic Botany Monographs, 72, 1-169.

Weisenberger, L.A., Weller, S.G. \& SaKai, A.K. (2014) Remnants of populations provide effective source material for reintroduction of an endangered Hawaiian plant, Schiedea kaalae (Caryophyllaceae). American Journal of Botany, 101, 1954-1962.
Weller, S.G. \& SAKAI, A.K. (1991) The genetic basis of male sterility in Schiedea (Caryophyllaceae), an endemic Hawaiian genus. Heredity, 67, 265-273.

Weller, S.G., Sakai, A.K., Campbell, D.R., Powers, J.M., Peña, S. R., KeIr, M.J. et al. (2017) An enigmatic Hawaiian moth is a missing link in the adaptive radiation of Schiedea. New Phytologist, 213, 1533-1542.

Weller, S.G., SaKai, A.K., Culley, T.M., Campbell, D.R. \& Dunbar-Wallis, A.K. (2006) Predicting the pathway to wind pollination: heritabilities and genetic correlations of inflorescence traits associated with wind pollination in Schiedea salicaria (Caryophyllaceae). Journal of Evolutionary Biology, 19, 331-342.

Weller, S.G., Sakai, A.K., Culley, T.M., Campbell, D.R., NGo, P. \& Dunbar-Wallis, A.K. (2007) Sexually dimorphic inflorescence traits in a wind-pollinated species: heritabilities and genetic correlations in Schiedea adamantis (Caryophyllaceae). American Journal of Botany, 94, 1716-1725.

Weller, S.G., Sakai, A.K., Rankin, A.E., Golonka, A., Kutcher, B. \& Asнвy, K.E. (1998) Dioecy and the evolution of pollination systems in Schiedea and Alsinidendron (Caryophyllaceae: Alsinoideae) in the Hawaiian Islands. American Journal of Botany, $85,1377-1388$.

Weller, S.G., Sakai, A.K. \& Straub, C. (1996) Allozyme diversity and genetic identity in Schiedea and Alsinidendron

(Caryophyllaceae: Alsinoideae) in the Hawaiian Islands. Evolution, 50, 23-34.

Willyard, A., Wallace, L.E., Wagner, W.L., Weller, S.G., SAKai, A.K. \& Nepóroeff, M. (2011) Estimating the species tree for Hawaiian Schiedea (Caryophyllaceae) from multiple loci in the presence of reticulate evolution. Molecular Phylogenetics and Evolution, 60, 29-48.

\section{Biographical sketches}

AnN K. SAKai and Stephen G. Weller have longstanding interests in the evolution of the reproductive systems of Schiedea. WEIGANG YANG manages the University of California, Irvine, greenhouse and carried out additional crosses to produce seeds used in reintroduction. Susan Ching Harbin and Talia Portner are employed by the O'ahu Plant Extinction Prevention programme, which is charged with protecting O'ahu's rarest plant species. GREG MANSKer works for the Division of Forestry and Wildlife and manages propagation and outplanting of threatened plant species. MARIE BRUEGMANN worked for the U.S. Fish and Wildlife Service to prevent extinction of rare plant species throughout Hawai' $i$. 